\title{
FAKTOR YANG BERHUBUNGAN DENGAN KELELAHAN KERJA SUBYEKTIF PADA PERAWAT DI RSUD DR. MOHAMAD SOEWANDHIE SURABAYA
}

\author{
FACTORS RELATED TO SUBJECTIVE WORK FATIGUE ON NURSES \\ IN DR. MOHAMAD SOEWANDHIE SURABAYA
}

\author{
Dita Perwitasari, Abdul Rohim Tualeka \\ Departemen Keselamatan dan Kesehatan Kerja \\ Fakultas Kesehatan Masyarakat Universitas Airlangga \\ E-mail: ditaperwita15@yahoo.co.id
}

\begin{abstract}
Fatigue is a subjective feeling that different for everyone, which leads to loss of efficiency, decreases work capacity, health problem and the body's ability to survive resulting in work accident. The purpose of this research was examining the factors associated with subjective work fatigue on nurses working in dr. Mohamad Soewandhie hospital in Surabaya. This research was an observational study with cross sectional design. The respondents were nurses of emergency, outpatient, and inpatient units in dr. Mohamad Soewandhie hospital. The variables were individual factors were consisting of age, years of working life, nutritional status, gender, and occupational factors were consisting of the workload and the monotony condition of work toward work fatigue. Spearman correlation test was using to test the relationship of each factors, except the relationship of gender and the monotony condition were using Mann-Whitney. The results showed that the most of the respondents were 25-30 years old, female, 1-10 years of working life, had better nutritional status, had a moderate heavy workload and felt the monotony condition in her work. The result of fatigue measurement used the checklist which indicated that the most of the respondents experienced no relationship between age, gender, years of working life, workload, and the monotony condition the results also proved the existence of a relationship between nutritional status with $p=0.00$. It could be concluded that the nutritional status of nurse in dr. Mohamad Soewandhie hospital had a risk of causing fatigue.
\end{abstract}

Keywords: individual factors, occupational factors, and work fatigue

\begin{abstract}
ABSTRAK
Kelelahan merupakan suatu perasaan subjektif yang berbeda-beda setiap orang, semuanya berujung pada kehilangan efisiensi, penurunan kapasitas kerja, gangguan kesehatan dan kemampuan bertahan tubuh yang berakibat pada kecelakaan kerja. Tujuan dari penelitian ini adalah mempelajari faktor yang berhubungan dengan kelelahan kerja subjektif pada perawat di RSUD dr. Mohamad Soewandhie Surabaya. Penelitian ini adalah penelitian observasional dengan rancangan cross sectional. Responden adalah perawat unit UGD, Rawat Jalan dan Rawat Inap RSUD dr. Mohamad Soewandhie Surabaya. Variabel yang diteliti adalah faktor individu yang terdiri dari umur, masa kerja, status gizi, dan jenis kelamin dan faktor pekerjaan yang terdiri dari beban kerja dan keadaan monoton terhadap kelelahan kerja. Uji hubungan menggunakan uji korelasi Spearman dan Mann-Whitney. Hasil penelitian menunjukkan bahwa sebagian besar perawat di RSUD dr. Mohamad Soewandhie memiliki umur 25-30 tahun, berjenis kelamin perempuan, memiliki masa kerja 1-10 tahun, berstatus gizi normal, beban kerja sedang merasakan dan keadaan monoton dalam pekerjaannya. Hasil pengukuran kelelahan menggunakan checklist menunjukkan bahwa sebagian besar perawat mengalami kelelahan sedang. Hasil penelitian membuktikan bahwa tidak ada hubungan antara umur, jenis kelamin, masa kerja dan beban kerja dengan kelelahan. Hasil penelitian juga membuktikan adanya hubungan antara status gizi dengan kelelahan (nilai $\mathrm{p}=0,000$ ). Kesimpulan penelitian menunjukkan status gizi perawat di RSUD dr. Mohamad Soewandhie Surabaya berisiko menyebabkan kelelahan kerja.
\end{abstract}

Kata kunci: faktor individu, faktor pekerjaan, dan kelelahan kerja 


\section{PENDAHULUAN}

Rumah sakit adalah bagian internal dari keseluruhan sistem pelayanan kesehatan yang dikembangkan melalui rencana pembangunan kesehatan sebagaimana yang digariskan dalam GBHN serta peraturan perundang-undangan di bidang kesehatan yang ada pada saat ini. Rumah sakit menyelenggarakan pelayanan kesehatan yang sifatnya komprehensif, yaitu meliputi upaya kuratif, rehabilitatif, promotif maupun preventif.

Rumah sakit sebagai pelayanan kesehatan perorangan dan merupakan bagian dari sumber daya kesehatan yang sangat diperlukan dalam mendukung penyelenggaraan upaya kesehatan. Penyelenggaraan pelayanan kesehatan di rumah sakit mempunyai karakteristik dan organisasi yang sangat kompleks. Berbagai jenis tenaga kesehatan dengan perangkat keilmuan yang beragam, berinteraksi satu sama lain.

Rumah sakit merupakan institusi yang bergerak dalam industri pelayanan kesehatan. Tugas rumah sakit adalah memberi pelayanan kesehatan dengan mengutamakan penyembuhan pasien dan pemulihan keadaan cacat badan dan jiwa yang dilaksanakan terpadu dengan upaya peningkatan kesehatan dan pencegahan penyakit serta melaksanakan upaya rujukan (Depkes RI, 1992).

Salah satu faktor yang mendukung keyakinan di atas adalah kenyataan yang dapat dilihat dari setiap instalasi pelayanan kesehatan di rumah sakit, dimana para tenaga kesehatan selama 24 jam harus berada disisi pasien adalah tenaga perawat (Wahyuningsih, 2003).

Keberadaan perawat sebagai ujung tombak pelayanan harus sangat diperhatikan dan dikelola secara profesional sehingga memberikan kontribusi yang positif bagi masyarakat dan juga untuk kemajuan Rumah sakit itu sendiri. Mutu Rumah Sakit sangat dipengaruhi oleh beberapa faktor. Adapun faktor yang paling dominan adalah sumber daya manusia. Sumber daya manusia yang terlibat secara langsung dalam pemberian pelayanan keperawatan pasien adalah dokter, perawat, bidan, serta tenaga penunjang lainnya. Diantara tenaga tersebut, tenaga perawat menempati urutan jumlah terbanyak yaitu 40\% (Dep. Kes. RI, 2005).

Salah satu permasalahan yang sering muncul di suatu rumah sakit adalah beban kerja perawat yang tidak seimbang yang dapat menyebabkan terjadinya kelelahan kerja pada tenaga kerja perawat. Walaupun seringkali manajer sulit untuk mengetahui kualitas beban kerja tersebut karena lebih mendasarkan pada keluhan yang bersifat subjektif (Ilyas, 2004).

Kelelahan merupakan suatu masalah kesehatan kerja yang perlu mendapat perhatian khusus. Kelelahan bagi setiap orang, bersifat subjektif karena terkait dengan perasaan, karena selain dipengaruhi oleh faktor fisik dan biologis, kelelahan juga dipengaruhi oleh faktor psikis (psikologi).

Kelelahan adalah salah satu faktor yang dapat mengurangi kapasitas kerja dan ketahanan tubuh pekerja. Terdapat dua jenis kelelahan yaitu kelelahan otot dan kelelahan umum. Kelelahan otot merupakan tremor pada otot. Kelelahan umum ditandai dengan berkurangnya kemauan untuk bekerja yang sebabnya adalah persyaratan psikis. Penyebab kelelahan umum adalah monotoni, intensitas, dan lamanya kerja mental dan fisik, keadaan lingkungan (Suma'mur, 2009).

Rumah Sakit Dr. Kariadi Semarang merupakan rumah sakit dengan jumlah pasien yang sangat banyak. Rata-rata jumlah kunjungan pasien rawat jalan di Rumah Sakit Dr. Kariadi sebanyak 650 orang/hari. Jumlah perawat di rawat jalan yang tersedia hanya 45 orang dengan berbagai tingkat pendidikan, umur, jenis kelamin, lama bekerja dan status kesehatan. Perawat masih belum cepat menangani permintaan keluhan pasien dan memberikan informasi yang jelas terhadap pasien. Menunjukkan bahwa sebanyak $56,70 \%$ perawat mengalami kelelahan kerja subjektif pada tingkat cukup lelah, $38,30 \%$ perawat mengalami kelelahan kerja subjektif pada tingkat sangat lelah. Jadi, dapat disimpulkan bahwa jika jumlah perawat tidak sebanding dengan jumlah pasien maka cepat mengalami kelelahan sehingga produktivitas kerja menurun. Produktivitas kerja sebenarnya mencakup tentang suatu sikap mental yang selalu mempunyai pandangan kehidupan mengenai pelaksanaan produksi di dalam suatu perusahaan, dalam memproduksi untuk hari ini diharapkan lebih baik dari hari kemarin begitu juga sistem kerjanya. Seseorang selalu mencari perbaikan dengan berpikir dinamis, kreatif serta terbuka.

Peningkatan produktivitas yang berarti jumlah sumber daya yang digunakan dengan jumlah barang dan jasa yang diproduksi semakin meningkat dan membaik. Menurut Moekijat (1999), produktivitas adalah Perbandingan jumlah keluaran (output) tertentu dengan jumlah masukan (input) tertentu untuk jangka waktu tertentu. Hasil observasi dilihat dari jumlah perawat yang bekerja di RSUD dr. Mohamad Soewandhie dengan pasien tidak 
seimbang, dikarenakan jumlah pasien yang berada di rumah sakit terlalu banyak. Sehingga perawat mengalami kelelahan dalam bekerja. Pada unit UGD kunjungan pasien tahun 2011-2012 meningkat $4,32 \%$ dibandingkan tahun lalu. Unit rawat jalan dan rawat inap pada tahun 2011-2012 sebanyak $20,47 \%$ sehingga tidak seimbangnya pasien dengan jumlah perawat yang ada di RSUD dr. Mohamad Soewandhie.

RSUD dr. Mohamad Soewandhie merupakan rumah sakit milik Pemerintah Kota Surabaya. Secara resmi mulai beroperasi tanggal 23 November 1998 dengan diterbitkannya Surat Keputusan Walikota Kepala Daerah Tingkat II Surabaya Nomor 94 tahun 1998 tentang pembentukan Organisasi dan Tata Kerja Rumah Sakit Umum Daerah Tambakrejo Kotamadya Surabaya. RSUD dr. Mohamad Soewandhie meningkat statusnya menjadi Rumah Sakit Kelas B Non-Pendidikan melalui Surat Keputusan Menteri Kesehatan RI 371/Menkes/SK/V/2009 tanggal 13 Mei 2009.

Dalam meningkatkan efisiensi dan efektivitas penyelenggaraan pelayanan kesehatan bagi masyarakat, lembaga pelayanan publik RSUD dr. Mohamad Soewandhie ditetapkan sebagai Badan Layanan Umum Daerah dengan status penuh, berdasarkan Surat Keputusan Walikota Surabaya Nomor 188.45/251/436.1.2/2009 tanggal 23 Mei 2009.

Hasil observasi dilihat dari jumlah perawat yang bekerja di RSUD dr. Mohamad Soewandhie dengan pasien tidak seimbang, dikarenakan jumlah pasien yang berada di rumah sakit terlalu banyak. Sehingga perawat mengalami kelelahan dalam bekerja.

Berdasarkan dari beberapa hasil penelitian tersebut banyak faktor yang berhubungan dengan kelelahan perawat di RSUD dr. Mohamad Soewandhie. Dari uraian di atas, peneliti tertarik untuk meneliti faktor yang berhubungan dengan kelelahan kerja pada perawat di RSUD dr. Mohamad Soewandhie.

Kelelahan kerja dapat dipengaruhi oleh banyak faktor, antara lain faktor individu, faktor pekerjaan, faktor lingkungan, dan faktor psikologis. Faktor individu meliputi umur, masa kerja, status gizi, dan jenis kelamin. Faktor pekerjaan meliputi beban kerja dan keadaan monoton. Faktor lingkungan meliputi penerangan, suhu ruangan, dan kebisingan. Faktor psikologis meliputi hubungan dengan pekerja lain.

Faktor-faktor yang diteliti dibatasi pada faktor individu dan faktor pekerjaan karena kedua faktor tersebut memberikan dampak terhadap kemampuan fisik pekerja untuk melakukan pekerjaan. Faktor lingkungan tidak diteliti karena berdasarkan hasil observasi yang dilakukan ketika survei awal, tidak ditemukan lingkungan kerja yang ekstrem seperti suhu, penerangan ataupun kebisingan.

\section{METODE}

Metode yang digunakan dalam pengumpulan datanya termasuk penelitian observasional karena data yang diperoleh tanpa adanya perlakuan pada obyek penelitian. Dari segi waktu, penelitian ini termasuk penelitian cross sectional karena pengambilan data dilakukan pada satu waktu. Kemudian jika ditinjau dari analisisnya, penelitian ini merupakan penelitian analitik. Cara pengambilan sampel yang diteliti ditentukan dengan mengunakan teknik stratified random sampling. Setiap anggota dari populasi sampel mempunyai kesempatan yang sama untuk diseleksi menjadi sampel. Dari populasi perawat bisa diambil 112 orang secara acak. Setiap perawat memiliki kesempatan yang sama untuk dipilih.

Penelitian dilakukan di Rumah Sakit Umum Daerah dr. Mohamad Soewandhie Tambakrejo, Surabaya. Penelitian dilakukan pada bulan April 2013-Juni 2013. Kegiatan penelitian meliputi prasurvey, persiapan, pelaksanaan, pengolahan, analisis data dan laporan hasil penelitian.

Variabel yang diukur dalam penelitian ini, adalah faktor individu (umur, masa kerja, status gizi, dan jenis kelamin), faktor pekerjaan perawat (beban kerja dan keadaan monoton), dan keadaan kelelahan yang dirasakan oleh perawat.

Pengumpulan data yang dilakukan untuk mengetahui adanya perbedaan pada perawat bagian UGD, rawat inap dan rawat jalan terhadap keluhan kelelahan yaitu dengan menggunakan kuesioner yang dibagikan kepada perawat dan didampingi oleh peneliti untuk mengisi kuesioner yaitu dari kelelahan kerja yaitu mengenai faktor individu (umur, jenis kelamin, masa kerja dan status gizi), faktor pekerjaan (beban kerja, keadaan monoton) pada perawat di RSUD dr. Mohamad Soewandhie Surabaya. Instrument yang digunakan dalam pengumpulan data penelitian ini menggunakan bantuan kuesioner. Kuesioner tentang kelelahan kerja, faktor individu dan faktor pekerjaan di RSUD dr. Mohamad Soewandhie Surabaya.

Data yang didapat dari hasil penelitian kemudian dianalisis dengan menggunakan teknik statistik. Teknik statistik yang digunakan untuk mengetahui hubungan adalah dengan menggunakan 
uji korelasi Spearman dan Mann-Whitney. Uji korelasi Spearman digunakan untuk analisis hubungan antara variabel umur, masa kerja, status gizi, dan beban kerja dengan kelelahan kerja. Uji Mann-Whitney digunakan untuk analisis hubungan antara variabel jenis kelamin dan keadaan monoton dengan kelelahan kerja.

\section{HASIL}

Jenis kelamin responden dalam penelitian ini dibedakan menjadi laki-laki dan perempuan. Distribusi responden di RSUD dr. Mohamad Soewandhie Surabaya. Pada laki-laki sebanyak 40 orang $(35,7 \%)$ dan perempuan 72 orang $(64,3 \%)$. Jadi berdasarkan jenis kelamin perawat di RSUD dr. Mohamad Soewandhie, sebagian besar berjenis kelamin perempuan sebanyak 72 orang $(64,3 \%)$.

Distribusi status gizi perawat dalam penelitian ini dihitung berdasarkan Body Mass Index (BMI) dan dibagi menjadi tiga kategori yaitu kurang, normal dan lebih. Status gizi kurang sebanyak 4 orang $(3,6 \%)$, normal 70 orang $(62,5 \%)$ dan lebih 38 orang $(33,9 \%)$ menunjukkan bahwa berdasarkan status gizi di RSUD dr. Mohamad Soewandhie, sebagian besar memiliki gizi normal sebanyak 70 orang $(62,5 \%)$.

Distribusi responden terhadap beban kerja yang dibedakan menjadi tiga kategori yaitu ringan, sedang, dan berat. Distribusi responden berdasarkan beban kerja di RSUD dr. Mohamad Soewandie Surabaya dapat dilihat dari ringan sebanyak 3 orang $(2,7 \%)$, sedang 76 orang $(67,9 \%)$, berat 33 orang $(29,5 \%)$. Dari hasil di atas menunjukkan bahwa berdasarkan beban kerja perawat di RSUD dr. Mohamad Soewandhie, sebagian besar mempunyai beban kerja sedang sebanyak 76 orang $(67,9 \%)$.

Distribusi frekuensi perawat terhadap keadaan monoton yang dirasakan pada perawat di RSUD dr. Mohamad Soewandhie Surabaya dapat dibedakan menjadi dua yaitu monoton dan tidak monoton.
Hasil monoton yaitu sebesar 64 orang $(57,1 \%)$ dan tidak monoton 48 orang $(42,9 \%)$. Jika dilihat menunjukkan bahwa perawat di RSUD dr. Mohamad Soewandhie, sebagian besar menyatakan bahwa pekerjaan yang mereka lakukan tergolong monoton sebanyak 64 orang $(57,1 \%)$.

Tabel 1 menunjukkan bahwa mayoritas responden yang mengalami kelelahan kerja adalah berjenis kelamin perempuan, sebagian besar mengalami tingkat kelelahan sedang sebanyak 32 orang $(44,4 \%)$.

Hubungan antara jenis kelamin responden dengan kejadian kelelahan dianalisis menggunakan uji Mann-Whitney diperoleh nilai $\mathrm{p}=0,572 \alpha=$ $0,05(p>\alpha)$ maka Ho diterima sehingga dapat disimpulkan bahwa tidak ada hubungan antara jenis kelamin dengan kelelahan yang dirasakan oleh perawat di RSUD dr. Mohamad Soewandhie.

Tabel 2 menunjukkan bahwa mayoritas responden yang mengalami kelelahan kerja mempunyai status gizi normal, sebagian besar mengalami tingkat kelelahan sedang sebanyak 33 orang $(46,7 \%)$.

Hubungan antara status gizi responden dengan kejadian kelelahan dianalisis menggunakan uji korelasi spearman diperoleh nilai $\mathrm{p}=0,000 \alpha=0,05$ $(\mathrm{p}<\alpha)$ maka Ho ditolak sehingga dapat disimpulkan bahwa ada hubungan antara status gizi dengan kelelahan yang dirasakan oleh perawat di RSUD dr. Mohamad Soewandhie.

Tabel 3 menunjukkan bahwa mayoritas responden yang mengalami kelelahan kerja adalah mempunyai beban kerja sedang, sebagian besar mengalami tingkat kelelahan sedang sebanyak 29 orang $(38,2 \%)$.

Hubungan antara beban kerja responden dengan kejadian kelelahan dianalisis menggunakan uji korelasi spearman diperoleh nilai $\mathrm{p}=0,618$ $\alpha=0,05(\mathrm{p}>\alpha)$, maka Ho diterima sehingga dapat disimpulkan bahwa tidak ada hubungan antara beban

Tabel 1. Distribusi Silang antara Jenis Kelamin Responden dan Kejadian Kelelahan pada Perawat di RSUD dr. Mohamad Soewandhie Surabaya, Mei 2013

\begin{tabular}{|c|c|c|c|c|c|c|c|c|}
\hline \multirow{3}{*}{$\begin{array}{c}\text { Jenis } \\
\text { Kelamin }\end{array}$} & \multicolumn{6}{|c|}{ Kelelahan } & \multirow{3}{*}{ Jumlah } & \multirow{3}{*}{$\%$} \\
\hline & \multicolumn{2}{|c|}{ Rendah } & \multicolumn{2}{|c|}{ Sedang } & \multicolumn{2}{|c|}{ Tinggi } & & \\
\hline & $\mathbf{n}$ & $\%$ & $\mathbf{n}$ & $\%$ & $\mathbf{n}$ & $\%$ & & \\
\hline Laki-laki & 7 & 17,5 & 16 & 40 & 17 & 42,5 & 40 & 100 \\
\hline Perempuan & 19 & 26,4 & 32 & 44,4 & 21 & 29,2 & 72 & 100 \\
\hline
\end{tabular}


Tabel 2. Distribusi Silang antara Status Gizi Responden dan Kejadian Kelelahan pada Perawat di RSUD dr. Mohamad Soewandhie Surabaya, Mei 2013

\begin{tabular}{|c|c|c|c|c|c|c|c|c|}
\hline \multirow{3}{*}{ Status Gizi } & \multicolumn{6}{|c|}{ Kelelahan } & \multirow{3}{*}{ Jumlah } & \multirow{3}{*}{$\%$} \\
\hline & \multicolumn{2}{|c|}{ Rendah } & \multicolumn{2}{|c|}{ Sedang } & \multicolumn{2}{|c|}{ Tinggi } & & \\
\hline & n & $\%$ & $\mathbf{n}$ & $\%$ & $\mathbf{n}$ & $\%$ & & \\
\hline Kurang & 3 & 75 & 0 & 0 & 1 & 25 & 4 & 100 \\
\hline Normal & 21 & 30 & 33 & 47,1 & 16 & 22,9 & 70 & 100 \\
\hline Lebih & 2 & 5,3 & 15 & 39,5 & 21 & 53,3 & 9 & 100 \\
\hline
\end{tabular}

kerja dengan kelelahan yang dirasakan oleh perawat di RSUD dr. Mohamad Soewandhie.

Tabel 4 menunjukkan bahwa mayoritas responden yang mengalami kelelahan kerja adalah merasaan keadaan monoton pada pekerjaannya, sebagian besar mengalami tingkat kelelahan sedang sebanyak 26 orang $(40,6 \%)$.

Hubungan antara beban kerja responden dengan kejadian kelelahan dianalisis menggunakan uji Mann-Whitney diperoleh nilai $\mathrm{p}=0,544$ $\alpha=0,05(\mathrm{p}>\alpha)$ maka Ho diterima sehingga dapat disimpulkan bahwa tidak ada hubungan antara keadaan monoton dengan kelelahan yang dirasakan oleh perawat di RSUD dr. Mohamad Soewandhie.

\section{PEMBAHASAN}

Jenis Kelamin Perawat di RSUD dr. Mohamad Soewandhie

Hasil penelitian menunjukkan bahwa perawat di RSUD dr. Mohamad Soewandhie adalah berjenis kelamin laki-laki (35,7\%) dan perempuan $(64,3 \%)$. Mayoritas perawat di RSUD ini adalah berjenis kelamin perempuan.

Pekerjaan yang dilakukan di rumah sakit utamanya unit UGD, rawat jalan dan rawat inap memerlukan tenaga ekstra untuk melakukan tindakan keperawatan terhadap pasien seperti mendorong kursi roda dan tempat tidur, membantu mengangkat pasien ataupun tindakan darurat lainnya. Oleh karena itu, perawat laki-laki lebih dibutuhkan untuk melakukan pekerjaan di rumah sakit. Hal ini

Tabel 3. Distribusi Silang antara Beban Kerja Responden dan Kejadian Kelelahan pada Perawat di RSUD dr Mohamad Soewandhie Surabaya, Mei 2013

\begin{tabular}{|c|c|c|c|c|c|c|c|c|}
\hline \multirow{3}{*}{ Beban kerja } & \multicolumn{6}{|c|}{ Kelelahan } & \multirow{3}{*}{ Jumlah } & \multirow{3}{*}{$\%$} \\
\hline & \multicolumn{2}{|c|}{ Rendah } & \multicolumn{2}{|c|}{ Sedang } & \multicolumn{2}{|c|}{ Tinggi } & & \\
\hline & $\mathbf{n}$ & $\%$ & n & $\%$ & $\mathbf{n}$ & $\%$ & & \\
\hline Ringan & 0 & 0 & 1 & 33,3 & 2 & 66,7 & 3 & 100 \\
\hline Sedang & 22 & 28,9 & 29 & 38,2 & 25 & 32,9 & 76 & 100 \\
\hline Berat & 4 & 12,1 & 18 & 54,5 & 11 & 33,3 & 33 & 100 \\
\hline
\end{tabular}

Tabel 4. Distribusi Silang antara Keadaan Monoton Responden dan Kejadian Kelelahan pada Perawat di RSUD dr. Mohamad Soewandhie Surabaya, Mei 2013

\begin{tabular}{|c|c|c|c|c|c|c|c|c|}
\hline \multirow{3}{*}{ Keadaan monoton } & \multicolumn{6}{|c|}{ Kelelahan } & \multirow{3}{*}{ Jumlah } & \multirow{3}{*}{$\%$} \\
\hline & \multicolumn{2}{|c|}{ Rendah } & \multicolumn{2}{|c|}{ Sedang } & \multicolumn{2}{|c|}{ Tinggi } & & \\
\hline & $\mathbf{n}$ & $\%$ & $\mathbf{n}$ & $\%$ & $\mathbf{n}$ & $\%$ & & \\
\hline Monoton & 16 & 25 & 26 & 40,6 & 22 & 34,4 & 64 & 100 \\
\hline Tidak monoton & 10 & 20,8 & 22 & 45,8 & 16 & 33,3 & 48 & 100 \\
\hline
\end{tabular}


disebabkan karena perawat yang berjenis kelamin laki-laki tidak mudah lelah daripada perawat perempuan (Tarwaka, 2004).

Menurut Tarwaka (2004), kerja fisik perempuan mempunyai volume oksigen maksimal $15-30 \%$ lebih rendah dibandingkan laki-laki. Kondisi ini disebabkan presentase lemak tubuh perempuan lebih tinggi dan kadar $\mathrm{Hb}$ darah lebih rendah dari laki-laki. Dengan demikian perempuan cenderung mengalami kelelahan kerja.

\section{Status Gizi Perawat di RSUD dr. Mohamad Soewandhie}

Hasil penelitian menunjukkan bahwa perawat di RSUD dr. Mohamad Soewandhie memiliki status gizi normal (BMI 18,5-25). Status gizi dapat memengaruhi tingkat kecepatan, ketepatan, dan keakuratan pekerjaan perawat. Jika pekerjaan dilakukan dengan cepat, tepat, dan akurat maka keadaan darurat yang terjadi bisa segera diatasi dengan baik. Status gizi juga dapat berpengaruh terhadap terjadinya risiko kelelahan kerja.

Selain mayoritas perawat memiliki status gizi normal, masih ditemukan perawat dengan status gizi lebih $(33,9 \%)$ dan kurang $(3,6 \%)$. Masalah ini seharusnya mendapatkan perhatian, yakni sebaiknya pihak rumah sakit memberikan penyuluhan tentang gizi dan pola makan agar status gizi perawat menjadi lebih baik.

Pendapat di atas juga sesuai dengan Suma'mur (2009) bahwa status gizi bila dikaitkan dengan kelelahan, status gizi kurang cenderung lebih mudah untuk mengalami suatu kelelahan karena keterbatasan atau ketidakseimbangan cadangan gizi yang akan diubah menjadi energi saat beraktivitas. Artinya apabila asupan gizi tidak sesuai dengan kebutuhannya maka tenaga kerja tersebut akan merasa lelah dibandingkan dengan perawat yang asupan gizinya memadai.

Pihak rumah sakit sebaiknya memberikan pengetahuan tentang gizi dan pola makan agar status gizi perawat menjadi normal dan baik. Usaha perbaikan status gizi perawat menjadi normal dan lebih baik. Usaha perbaikan gizi perawat dilakukan oleh petugas unit gizi dan metode yang digunakan adalah melalui penyuluhan dengan mengundang seluruh perawat sehingga perawat mengerti tentang pentingnya status gizi normal.

\section{Beban Kerja Perawat di RSUD dr. Mohamad Soewandhie}

Hasil penelitian menunjukkan bahwa perawat UGD dan rawat jalan paling banyak bekerja dengan beban kerja sedang, yaitu $40 \%$ waktu untuk duduk atau berdiri dan sebanyak $60 \%$ waktu untuk melakukan pekerjaan khusus. Beban kerja terkait dengan pekerjaan yang dilakukan perawat, seperti mengerjakan tugas administrasi dan manajemen, memasang infus, memandikan pasien, menyuapi pasien, mengobservasi keadaan pasien, menyuntik pasien, menyiapkan tempat tidur, mengukur suhu tubuh pasien, mengukur tekanan darah pasien, merawat luka pasien, sterilisasi alat kesehatan, dan menyiapkan tempat tidur.

Menurut Suma'mur (2009) beban kerja menentukan lama seseorang dapat bekerja sesuai dengan kapasitas kerjanya. Seseorang yang bekerja dengan beban kerja yang terlalu berat yang tidak sebanding dengan kapasitas kerjanya maka dapat menyebabkan terjadinya kelelahan. Energi yang dibutuhkan akan semakin banyak apabila otot semakin lama berkontraksi melawan beban yang diperolehnya. Energi pemulihan saat relaksasi yang tidak sebanding menyebabkan timbulnya kelelahan.

\section{Keadaan Monoton Perawat di RSUD dr. Mohamad Soewandhie}

Hasil penelitian menunjukkan bahwa sebagian besar perawat di RSUD dr. Mohamad Soewandhie mengalami keadaan monoton $(57,1 \%)$ disebabkan oleh pekerjaan yang sama dilakukan berulang-ulang dan lingkungan kerja yang tidak menyenangkan. Menurut Anoraga (2001), kelelahan berhubungan erat dengan perasaan bosan akibat pekerjaan yang monoton meskipun faktor penyebab timbulnya kondisi tersebut sangat berbeda. Pekerjaan yang dilakukan berulang-ulang dari hari ke hari tanpa adanya variasi dapat menimbulkan rasa jenuh, bosan dan cepat lelah. Keadaan monoton juga dapat berasal dari lingkungan kerja yang tidak menyenangkan baik antar perawat maupun penataan ruangan

\section{Hubungan antara Jenis Kelamin dengan Kelelahan}

Hasil penelitian menunjukkan bahwa perawat di RSUD dr. Mohamad Soewandhie yang paling banyak mengalami kelelahan adalah berjenis 
kelamin perempuan. Laki-laki dan wanita memiliki kemampuan fisik, kekuatan kerja otot yang berbeda (Suma'mur, 1994). Secara umum wanita hanya mempunyai kekuatan fisik 2/3 dari kemampuan fisik atau kekuatan otot laki-laki tetapi dalam hal tertentu wanita lebih teliti daripada laki-laki.

Menurut Konz (1996), dalam Tarwaka dkk (2004), untuk kerja fisik, wanita mempunyai volume oksigen maksimal $15-30 \%$ lebih rendah dibandingkan laki-laki. Kondisi ini disebabkan presentase lemak tubuh perempuan lebih tinggi dan kadar $\mathrm{Hb}$ darah lebih rendah dari laki-laki. Hal ini yang menyebabkan perempuan cenderung mengalami kelelahan kerja. Berdasarkan pembahasan di atas dapat disimpulkan bahwa perempuan lebih cepat merasakan kelelahan daripada laki-laki.

Menurut uji statistik Mann-Whitney hubungan antara jenis kelamin dengan kelelahan pada perawat menunjukkan diperoleh nilai $p=0,572 \alpha$ $=0,05(\mathrm{p}>\alpha)$, maka tidak ada hubungan antara jenis kelamin responden dengan kelelahan. Tidak adanya hubungan ini memiliki arti bahwa banyak faktor yang memengaruhi kelelahan dan faktor jenis kelamin bukan merupakan faktor yang berhubungan secara langsung dengan terjadinya kelelahan.

\section{Hubungan antara Status Gizi dengan Kejadian Kelelahan}

Hasil penelitian menunjukkan bahwa perawat di RSUD dr. Mohamad Soewandhie mayoritas mengalami kelelahan adalah perawat dengan status gizi normal. Masih ditemukan pula perawat dengan status gizi lebih cukup banyak $(39,5)$. Kelelahan yang dialami sebagian besar perawat dalam hal ini adalah tingkat kelelahan sedang.

Gizi kerja adalah pemberian gizi yang diterapkan kepada masyarakat pekerja dengan tujuan untuk meningkatkan derajat kesehatan, efisiensi, dan produktivitas kerja yang setinggi-tingginya. Dalam upaya memelihara kesehatan tenaga kerja, perusahaan seharusnya memperhatikan kecukupan gizi pekerjanya setiap hari (Tarwaka, 2004).

Tubuh dalam melakukan pekerjaan memerlukan energi. Kapasitas kerja dapat terganggu bila kekurangan, baik secara kuantitatif maupun kualitatif. Keseimbangan antar intake energi dan output yang harus dikeluarkan sangat diperlukan. Nutrisi yang baik saja tidak cukup, untuk itu diperlukan adanya kondisi tubuh yang sehat pula agar nutrisi dapat dicerna dan didistribusikan oleh organ tubuh (Tarwaka, 2004).
Menurut Suma'mur (2001) status gizi bila dikaitkan dengan kelelahan maka status gizi yang kurang cenderung lebih mudah untuk mengalami suatu kelelahan karena keterbatasan atau ketidakseimbangan cadangan gizi yang akan diubah menjadi energi saat beraktivitas. Hal ini diperkuat oleh pendapat Suhardjo (2002) bahwa jika mengonsumsi zat makanan secara berlebih akan dapat menyebabkan kelebihan energi oleh tubuh, sehingga menimbun asam laktat dalam tubuh dan tubuh akan cepat menjadi lelah. Mengonsumsi zat makanan kurang dapat menyebabkan tubuh mengubah cadangan makanan menjadi energi untuk melakukan pekerjaanya sehingga tubuh akan bekerja lebih keras dan cepat menimbulkan kelelahan. Berdasarkan pembahasan di atas dapat disimpulkan bahwa sebagian besar perawat memiliki keseimbangan antara intake dan output (status gizi normal) sehingga memungkinkan perawat dapat terhindar dari terjadinya kelelahan kerja.

Menurut hasil uji statistik korelasi Spearman hubungan antara status gizi dengan kelelahan perawat di RSUD dr. Mohamad Soewandhie diperoleh nilai $\mathrm{p}=0,000 \alpha=0,05(\mathrm{p}<\alpha)$ maka ada hubungan antara status gizi dengan kelelahan yang dirasakan oleh perawat. Sehingga dapat disimpulkan bahwa status gizi merupakan faktor yang berhubungan langsung dengan kelelahan kerja.

\section{Hubungan antara Beban Kerja dengan Kelelahan}

Hasil penelitian menunjukkan bahwa mayoritas perawat di RSUD dr. Mohamad Soewandhie memiliki beban kerja sedang mengalami tingkat kelelahan sedang (38,2\%). Menurut Suma'mur (2009) setiap pekerjaan merupakan beban bagi pelakunya. Beban tersebut dapat berupa fisik, mental atau sosial.

Seorang tenaga kerja memiliki kemampuan tersendiri dalam hubungannya dengan beban kerja. Mereka mungkin ada yang lebih cocok dengan beban kerja fisik, mental atau sosial, namun sebagai persamaan. Mereka hanya mampu memikul beban sampai suatu berat tertentu sesuai dengan kapasitas kerjanya. Beban kerja yang semakin besar menyebabkan waktu seseorang dapat bekerja sesuai dengan kapasitas kerjanya. Beban kerja yang semakin besar menyebabkan waktu seseorang dapat bekerja tanpa mengalami kelelahan atau gangguan semakin pendek. 
Menurut Suma'mur (2009), beban kerja menentukan berapa lama seseorang dapat bekerja sesuai dengan kapasitas kerjanya. Seseorang yang bekerja dengan beban kerja yang terlalu berat yang tidak sebanding dengan kapasitas kerjanya maka dapat menyebabkan terjadinya kelelahan. Energi yang dibutuhkan akan semakin banyak apabila otot semakin lama berkontraksi melawan beban yang diperolehnya. Energi pemulihan saat relaksasi yang tidak sebanding menyebabkan timbulnya kelelahan.

Berdasarkan pembahasan di atas dapat disimpulkan bahwa kapasitas dan kemampuan kerja perawat tidak sebanding dengan beban kerjanya sehingga sebagian besar perawat yang memiliki beban kerja sedang mengalami kelelahan kerja.

Hasil uji statistik korelasi Spearman hubungan antara beban kerja dengan kelelahan kerja perawat di RSUD dr. Mohamad Soewandhie diperoleh nilai $\mathrm{p}=0,618 \alpha=0,05(\mathrm{p}>\alpha)$, maka tidak ada hubungan antara beban kerja dengan kelelahan yang dirasakan tenaga kerja perawat. Tidak adanya hubungan menunjukkan bahwa beban kerja bukan merupakan faktor yang berhubungan secara langsung dengan terjadinya kelelahan kerja.

\section{Hubungan Keadaan Monoton dengan Kelelahan}

Hasil penelitian menunjukkan bahwa perawat di RSUD dr. Mohamad Soewandhie paling banyak mengalami kelelahan kerja adalah perawat yang merasa pekerjaannya dilakukan secara monoton (40,6\%). Pekerjaan yang monoton atau dilakukan berulang-ulang dari hari ke hari tanpa adanya variasi dapat menyebabkan rasa jemu, bosan sehingga mempercepat timbulnya kelelahan kerja (Suma'mur, 1996). Hal ini juga dipertegas oleh pendapat dari Nurmianto (2004) kondisi kerja yang berulang-ulang dapat menimbulkan suasana monoton yang menjadi rasa bosan, rasa kebosanan dikategorikan sebagai kelelahan.

Menurut Anoraga (2001), kelelahan berhubungan erat dengan perasaan bosan akibat pekerjaan yang monoton meskipun faktor penyebab timbulnya kondisi tersebut sangat berbeda. Pekerjaan sama yang dilakukan berulang-ulang dari hari ke hari tanpa adanya variasi dapat menimbulkan rasa jemu, bosan dan cepat lelah. Keadaan monoton juga dapat berasal dari lingkungan kerja yaitu lingkungan kerja yang tidak menyenangkan baik dari penghuni maupun dekorasi dan penataan ruang.
Berdasarkan pembahasan di atas dapat disimpulkan bahwa perawat di RSUD dr. Mohamad Soewandhie mayoritas merasakan pekerjaan monoton yang dapat menyebabkan kelelahan kerja.

Hasil uji Mann-Whitney hubungan antara keadaan monoton pada perawat di RSUD dr. Mohamad Soewandhie diperoleh nilai $\mathrm{p}=0,544$ $\alpha=0,05(\mathrm{p}>\alpha)$, maka tidak ada hubungan antara keadaan monoton dengan kelelahan yang dirasakan oleh perawat. Tidak adanya hubungan ini menunjukkan bahwa keadaan monoton bukan merupakan faktor yang berhubungan secara langsung dengan terjadinya kelelahan kerja. Hal ini dapat disebabkan oleh pekerjaan yang dilakukan oleh perawat dipersepsikan sebagai keadaan monoton padahal sebenarnya itu hanya rutinitas yang harus dijalankan oleh perawat.

\section{SIMPULAN}

Berdasarkan aspek individu, sebagian besar perawat di RSUD dr. Mohamad Soewandhie memiliki kelompok umur 25-30 tahun, berjenis kelamin perempuan, memiliki masa kerja antara 1-10 tahun, dan mengalami status gizi normal.

Berdasarkan aspek pekerjaan, sebagian besar perawat memiliki beban kerja sedang dan merasakan keadaan monoton dalam pekerjaanya. Pada aspek kelelahan subjektif dengan menggunakan parameter IFRC diketahui bahwa sebagian besar perawat mengalami kelelahan sedang.

Faktor individu perawat yang meliputi umur, jenis kelamin, masa kerja menunjukkan bahwa tidak ada hubungan dengan kelelahan kerja. Sedangkan status gizi perawat menunjukkan bahwa ada hubungan dengan kelelahan kerja. Semua faktor pekerjaan perawat yang meliputi beban kerja dan keadaan monoton menunjukkan bahwa tidak ada hubungan dengan kelelahan kerja.

\section{DAFTAR PUSTAKA}

Anoraga, P. 2001. Psikologi Kerja. Jakarta: Rineka Cipta.

Asmara, Hening Puji. 2009 .Beberapa Faktor yang Berhubungan dengan Kelelahan pada Perawat Rumah Sakit Adi Husada Undaan Wetan Kota Surabaya. Skripsi. Surabaya: FKM Universitas Airlangga.

Depkes RI. 1996. Pedoman Praktis Pemantauan Status Gizi Orang Dewasa. Jakarta: Ditjen Binkesmas: 2-17. 
Depnaker dan Transmigrasi RI. 2003. UndangUndang Ketenagakerjaan RI No. 13 Tahun 2003. Jakarta.

Depnaker dan Transmigrasi RI. 2005. Himpunan Peraturan Keselamatan Kerja. Direktorat pengawasan Keselamatan Kerja Direktorat Jenderal Pembinaan Pengawasan Ketenagakerjaan Program Perlindungan dan Pengembangan Lembaga Tenaga Kerja. Jakarta.

Fa, Monika K. 2002. Prinsip Dasar Ilmu Keperawatan. Jakarta: PT. Gunung Agung.

Grandjean, E. 1995. Fitting the Task to the Man, 4th ed. London, New York, Philadelphia: Taylor \& Francis Inc, 156-173, 217-226.

Khumaidi, M. 1994. Bahan Pengajaran Gizi Masyarakat. Jakarta: Gunung Mulia.

Putra, Dhadang Widha. 2012. Hubungan Faktor Individu dan Faktor Pekerjaan dengan Kelelahan Perawat Shift Malam di Bagian IGD RSUD PROF. DR. SOEKANDAR Mojosari Kab. Mojokerto. Skripsi. Surabaya: FKM Universitas Airlangga.

Riza, Gigik M. 2011. Perbedaan Kelelahan pada Perawat Shift Pagi dan Shift Malam Bagian Rawat
Inap di Rumah Sakit Islam Surabaya. Skripsi. Surabaya: FKM Universitas Airlangga.

Setyawati, L. 2010. Selintas tentang Kelelahan Kerja. Yogyakarta: Amara Books.

Siswanto, A. 1991. Ergonomi. Balai Hiperkes dan Keselamatan Kerja Jawa Timur. Departemen Tenaga Kerja. Surabaya.

Suma'mur. 1996. Higiene Perusahaan dan Kesehatan Kerja. Jakarta: CV Haji Masagung.

Suma'mur, P. K. 1989. Ergonomi untuk Produktivitas Kerja. Jakarta: CV Haji Masagung.

Suma'mur. 2009. Higiene Perusahaan dan Kesehatan Kerja.(Hiperkes) Jakarta: CV Sagung Seto.

Suma'mur, P. K. 2010. Hygiene Perusahaan dan Kesehatan Kerja. Jakarta: CV Haji Masagung. Supariasa, I Dewa Nyoman, Bachtiar Bakri, Ibnu Fajar. 2001. Penilaian Status Gizi. Jakarta: ECG.

Tarwaka, Bakri dan Sudiajeng. 2004. Ergonomi untuk Keselamatan, Kesehatan Kerja dan Produktivitas. Surakarta: UNIBA Press.

Wignjosoebroto, Sritomo. 2008. Ergonomi Studi Gerak dan Waktu. Jakarta: PT. Guna Widya. 